\title{
A Value Chain Approach to Forest Landscape Restoration: Insights from Vietnam's Production-Driven Forest Restoration
}

\section{Nga Thi Ha ${ }^{1}$, Simon Benedikter ${ }^{1, *}$, Gerald Kapp ${ }^{1}$

\begin{abstract}
According to FAO figures, over 129 million hectares of forests have been lost globally since the 1990s, mainly in the tropical Global South, where agriculture acts as the main driver of forest conversion. International commitments, such as the Bonn Challenge, aim to reverse this trend through the application of forest landscape restoration (FLR) as an integrated and inclusive restoration approach. Beyond the discourse level, however, FLR implementation lags behind expectations due to insufficient funding and a disconnection with local implementation. We argue that, instead of relying on public resources for conservationdriven restoration, increased private sector engagement may point the way out of the funding impasse. However, this requires a shift towards production-driven FLR, which includes the livelihood needs of communities and smallholders as agents of landscape transition. For achieving the dual purpose of connecting landscapes with markets and promoting sustainable landscape restoration, we ascribe value chains and their economic, social and ecological configurations a key role in production-driven FLR. Drawing on Vietnam's forest restoration pathway as an illustrative case, we examine how production-driven forest restoration, smallholder engagement and value chain upgrading can stimulate positive landscape transitions. We conclude that, depending on their configuration, value chains can have negative or positive social and ecological impacts at the landscape level. Furthermore, regulated, progressive and high-value commodity chains may perform better in the areas of integrated FLR objectives landscape integrity, ecological functionality and human well-being.
\end{abstract}

\section{KEYWORDS}

forest landscape restoration, production-driven, vicious and benign value chains, tree plantations, acacia, smallholder inclusion, certification, landscape mosaic, Vietnam and Society. This work is licensed under a Creative Commons Attribution 4.0 International License

\section{INTRODUCTION: TOWARDS A PRODUCTION-DRIVEN AND INCLUSIVE FOREST LANDSCAPE RESTORATION (FLR) APPROACH}

\subsection{FLR: A new paradigm desperate for funding}

As climate change becomes increasingly perceptible, with all its adverse impacts, forests are moving into the limelight of global mitigation and adaptation efforts. Whilst their degradation fuels climate change, forests are indispensable in mitigating global warming due to their function as carbon sinks. Therefore, the loss of 129 million hectares of forest since the 1990s, mainly in tropical regions of the Global South (FAO, 2015), has had twice the impact. After decades of unhampered timber extraction and forest conversion through vicious cycles of degradation, this process must be stopped and reverted into a virtuous cycle of forest restoration. This, however, requires substantial investments in time, materials and/or money and benefits forgone from short-term unsustainable resource exploitation. To date, several commitments have been made to halt deforestation and promote large-scale forest restoration, such as the Bonn Challenge, which aims to restore 150 million hectares of forests by 2020 . In 
parallel, the Global Partnership on Forest and Landscape Restoration (GPFLR) emerged as its most prominent advocacy body, lobbying for FLR as a new paradigm in forest rehabilitation and ecosystem restoration. By definition, FLR includes any activity that aims to regain ecological integrity for improving human well-being by facilitating the transition from degraded lands to restored multifunctional landscapes (Maginnis \& Jackson, 2002).

Understanding what is new about FLR requires us to take stock of the failures of past reforestation paradigms. Past reforestation, more often than not, drew on sectoral approaches, ignoring the complex realities inherent to human-modified and mosaiclike landscapes comprising different land-use systems, such as cropping land, pastures, settlements and forests adjacent to each other. Such mosaic landscapes are particularly common in the Global South, where forest degradation is most acute due to agricultural expansions, high demand for fuelwood and minerals, urbanisation, infrastructure development and other forms of land conversion at the expenses of forests. In addition to agriculture, forests contribute greatly to rural livelihoods in the Global South through subsistence and the commercial use of timber and non-timber forest products. About $25 \%$ of the world population, or 1.6 billion people-mainly in the Global South-are estimated to rely on forests for their livelihoods, including fuelwood, fodder for livestock or medicinal plants (Agrawal et al., 2013). Dependency on forests is even higher if we include the vital environmental services they provide, such as watershed protection and soil conservation, both of which are critical to sustaining agricultural productivity (Rasmussen et al. 2017). Hence, different from past restoration efforts FLR seeks to integrate different land uses and the corresponding stakeholders at landscape level into a joint management process. To this end, livelihood diversification and landscape heterogeneity are considered important elements of FLR (Brancalion \& Chazdon 2017).

Encroachments and conflicts along forest-farm interfaces surrounding conservation sites can be found in tropical developing countries, as can be observed in parts of Africa and Asia (Moyo et al., 2017; Issara et al., 2019). They highlight the necessity of considering local livelihoods, food security and socio-economic development in forest restoration efforts. In addition, rural stagnation, poverty and the exclusion of local communities from forest resources have thwarted most of the forest conservation efforts in the Global South over the past decades (Nambiar, 2019). The fact that forests embody parts of complex patchwork landscapes with multiple stakeholders calls for a paradigm shift towards forest restoration in a more holistic and integrative sense. In this regard, Lamb et al. (2005) argues that, instead of restoring large-scale forest reserves in many developing countries, mosaic-oriented landscape restoration may be more appropriate in facilitating realistic trade-offs between conservation and human well-being. Globally, there are about 1.5 billion ha of degraded lands that are well-suited for mosaic restoration, in which multiple parallel land use systems for forestry, wetlands, pasture, settlement or intensive agriculture can be integrated (FAO, 2015). Drawing on the landscape approach, FLR opts for trade-offs that merge various land uses and corresponding stakeholders at the landscape level into an integrated management process (Lamb et al. 2005; Sayer et al., 2013; Mansourian, 2018).

Yet, beyond the discourse level, FLR implementation has been criticised for being far behind expectations, mainly due to insufficient funding (Reinecke \& Blum, 2018). No less than about USD 830 billion is required to achieve the New York Declaration on Forests, which aims to restore 350 million hectares by 2030 (Gritten et al., 2018). Over the past decades, forest restoration efforts have predominantly relied on public investments, the bulk of which have benefited conservation-oriented rehabilitation 
projects. Thus far, private investments have played a minor role. If the new Bonn Challenge and its ensuing initiatives want to keep their ambitious promise, additional funds must be mobilised, and the private sector is the most obvious source for doing so (Mansourian 2018; Sabogal et al., 2015).

\subsection{Towards smallholder inclusion in production-driven FLR}

Except for purely philanthropic-oriented forest and conservation efforts through private entities, large-scale private sector engagement requires a market-driven approach via commercial forestry. Nevertheless, as we can learn from concessionbased industrial tree plantations in the Global South, large-scale private investments in commercialised forestry have not always benefited the landscapes and their inhabitants. Since the 1990s, large-scale plantations have expanded more than fourfold throughout the Global South, with investments coming from large corporations and trust funds (Overbeek et al., 2012). Such large-scale and solely profit-oriented investments in commercial forestry frequently had negative environmental impacts, as they mostly prioritised economic returns over ecological and social sustainability (Sawyer, 1993; Cannell, 1999). Furthermore, institutional deficiencies have abetted land grabbing, local community exclusion, dispossession and conflicts (Overbeek et al., 2012; Kröger 2012). Such negative ecological and social outcomes collide fundamentally with FLR principles in which local stakeholder involvement, participatory governance and equal benefit sharing have the highest priority on the pathway to successful restoration efforts (Mansourian, 2016).

Pokorny \& De Jong (2015) critically reflect on large-scale commercial forestry as an alternative means of rural development and forest restoration, arguing that smallholders bear great potential to create environmentally stable landscapes that also bring about social and economic benefits for local communities. Similarly vein, RosTone et al. (2015) emphasise the role of smallholders in landscape approaches, as they operate at the interface of vertical relations with downstream commodity chain actors (traders, processors and exporters) and horizontal interactions in the landscape in which they sustain their livelihoods. Thus, smallholders must play a critical role as a target group when crafting sustainable FLR policies and practical interventions on the ground.

As market integration is advancing in the Global South, many smallholders have turned into private sector players producing for global and local commodity chains (Nambiar, 2019; Midgley et al., 2017). At the same time, with their diverse land use systems, smallholders hold the key to integrating trees in agricultural land use, both in the form of woodlots and agroforestry systems (Ros-Tone et al., 2015). Recent research from Africa and Asia reinforces the need to consider smallholders in locally adapted FLR approaches by providing attractive incentives to elicit their engagement (Owusu et al., 2021; Tran et al., 2018). Beyond additional income generation, integrating trees in small-scale farming systems increases social resilience by providing food, commodities and vital environmental services at different scales (Kapp \& Manning, 2014). This corresponds well with the notion of mosaic agriculture-FLR.

However, local communities in regions with high rates of deforestation and forest degradation are often poor, with farmers who own small plots of land and lack access to financial capital. Smallholders may also prioritise livelihood security over environmental sustainability (Lamb et al., 2005). In addition, in a mosaic landscape, farmers participate in various value chains that compete for the same household resources of land, labour, capital and entrepreneurship (Bolwig et al., 2010). Therefore, empowering smallholders in FLR must occur in parallel with crafting enabling institutional environments and conducive incentive policies. Only under conditions of secure land tenure and market access can smallholders be encouraged to integrate

Ha et al. (2022) 
trees into their land-use systems (Snelder \& Lasco, 2008). Forest devolution, combined with linking tree-growing smallholders to markets through innovative business models and value chain inclusion, paves the way towards market-oriented landscape restoration pathways in which economic rewards benefit smallholders, landscapes and the rest of society (Arts et al., 2017; Gritten et al., 2018). This notion of linking smallholders with processors and other private sector actors located down the value chain in economically viable approaches constitutes what we call a 'production-driven and inclusive FLR approach.'

Two main market-based mechanisms are currently used by international environmental policies to attract investments in FLR: (1) Payment for Ecosystem Services (PES), such as REDD+ or other voluntary or compliance carbon rewarding schemes; and (2) sustainable value chain development (Arts et al. 2017; FAO and Global Mechanisms of the UNCCD 2015). Whilst PES, especially REDD+, is widely promoted, value chain approaches towards FLR have received far less attention. Assuming that landscapes are embedded parts of (global) value chains, our purpose is to shed light on the nexus amongst value chains, smallholder inclusion and landscape restoration to achieve production-driven FLR. As will be demonstrated, value chain configurations can have positive or negative impacts on the degradation of landscapes. We postulate that unregulated and low-value commodity chains are more likely to generate negative impacts (we call this 'vicious VC'), whilst regulated and high-value commodity chains will generate positive impacts, specifically in terms of environmental integrity, local livelihood improvement, governance and private sector engagement (we call this 'benign VC').

\section{MATERIALS AND METHODS}

In the introduction we highlighted the relevance for production-driven and smallholder-inclusive FLR approaches in the Global South. In the ensuing section we explore the nexus between value chains and landscape approaches, and how both approaches interact with each other. Based on a literature review, we discuss and seek to conceptualize the interface between value chains and landscapes. The focus is on how value chain configurations and governance impact on landscapes, and how value chain upgrading, for instance enhanced (vertical and horizontal) collaboration among chain actors or certification and chain of custody, can yield positive socio-economic and environmental outcomes at landscapes level.

Subsequently, for testing the above postulate that 'benign VC' may elicit positive landscape outcomes, we will examine Vietnam's FLR pathway over the past 30 years. We selected Vietnam as a case study because the country increased its forest cover from $27 \%$ in 1990 to almost $42 \%$ in 2019 through production-driven reforestation policies. We specifically deal with acacia which has played a pivotal role in Vietnam's reforestation pathway. Our aim is to assess the shift from low-value to high-value acacia chains and the corresponding landscape impacts in social-economic and ecological terms. To this end, we look into two smallholder tree certification schemes, both located in Central Vietnam, more precisely in the provinces of Thua Thien-Hue and Quang Tri. Data used include secondary data derived from project reports, combined with interviews conducted in 2017 and 2020 with stakeholders involved in the two group certification schemes. The 2020 data was collected as part of a fact-finding-mission for planning a group certification project. The 2017 data was collected by one of the authors as part of an MSc thesis. Apart from key informant interviews with NGOs, local authorities, saw mills and the group leaders, the research design included semistructured interviews with 19 acacia growers participating in the group certification schemes. Visiting the project site twice in three years allowed to capture relevant 
changes.

\section{VALUE CHAINS AND LANDSCAPE RESTORATION: EXPLORING THE RELATIONSHIP}

\subsection{Understanding the origins of the problem}

The value chain concept constitutes a descriptive and analytical instrument to depict the full range of activities on the pathway of bringing a product or service from conception, through the different stages of production all the way down to its final consumers. It includes physical transformation and the input of various producer services, such as transportation and distribution. Along the value chain, we can trace how financial margins are shared amongst the chain actors and study power relations in value chain governance structures (Kaplinsky \& Morris 2001; Ribot, 1998; Trienekens 2012; Gereffi, 1999). In particular, value-chain mapping illustrates where actors are positioned geographically and within the chain structure, thereby indicating power structures related to flows of benefits and information (Helmsing \& Vellema 2011; Van Dijk \& Trienekens, 2012).

Potential products can be forest-related, such as food; timber, fuelwood and nontimber forest products; and carbon and other environmental services, such as watershed protection and soil conservation. Value chains can operate from local, national and global levels, connecting landscapes where raw materials are sourced to other landscapes where processors and consumers purchase them as raw materials, semi-products or final goods (Ingram, 2014). Therefore, value-chain analysis not only provides a framework for capturing the chain actors and their relationships across multiple scales and production steps, it can also be used as an instrument to trace how the decisions, actions and attitudes along the chain impact the (sourcing) landscapes.

In practice, value chain analysis is not an end in itself but the starting point for upgrading interventions. There are manifold options to manage the shift from lower- to higher-value activities through improvements in processes, products and functions, specifically regarding competitiveness and market access, diversification, value chain governance or collaboration and partnership development (McDermott, 2007; Trienekens \& Van Dijk, 2012; Gereffi, 1999). For instance, in the Global South, promoting horizontal collaboration amongst smallholders through the establishment of producer associations or cooperatives has become a means to reduce the production and transaction costs of smallholders whilst ensuring uniform quality standards and joint merchandise products for advanced market access (Coles \& Mitchell, 2011; Kilelu et al., 2017). Moreover, certification schemes that ensure compliance with good social and ecological standards in sourcing and production along the value chain have gained considerable importance as an upgrading strategy, particularly within Western markets.

\subsection{Impacts of value chains on landscapes: Vicious and benign value chains}

Be it in global or local markets, the commodification of any product or service inevitably creates a value chain along which the final product/service is delivered to the consumer. The emerging value chain can have positive and/or negative impacts on the sourcing landscape in ecological and social terms. For example, the industry that produces palm oil, a non-timber forest product now commercially cultivated in plantations, provides many illustrative cases of vicious value chains. Given the rising global demand for palm oil for food (e.g., vegetable oils) and industrial use (e.g., biofuels), governments in tropical countries are increasingly promoting palm oil cultivation for poverty reduction and rural development. Consequently, since 2000, the total global area of oil palm production has expanded, ranging from 10 million to 17 
million hectares by 2012. The bulk of global palm oil originates from Indonesia and Malaysia, where smallholders and out-growers have a stake in cultivation, apart from large-scale private and state-owned estates (Pirker et al., 2016). Indonesia, for instance, has an estimated 1.46 palm oil smallholders (Pacheco et al., 2017).

Whilst some studies underline the positive effects on grower communities regarding poverty alleviation and other socio-economic improvements (e.g., Löffler et al. 2014), general social and ecological concerns prevail, thereby making palm oil production a contested issue. In particular, huge areas of natural forests and forestagriculture mosaics have been converted into homogenous landscapes of palm oil monocultures. Resulting ecological impacts range from the loss of biodiversity to massive pollution through agrochemicals, which harm human health and the surrounding ecosystems. Moreover, the exclusion of indigenous people, land grabbing and eviction as well as the abuse of (migrant) workers in plantations and milling facilities are some of the negative social impacts attributed to transnational palm oil commodity chains (Pye \& Bhattacharya 2011). Nevertheless, the palm oil industry is not a problem per se, but rather its uncontrolled expansion in the form of unhealthy production systems due to weak (international) value chain governance arrangements. In fact, as shown by Sayer et al. (2012), apart from income generation, palm oil cultivation can generate environmental benefits for landscape restoration, such as a positive carbon balance, if grown in areas not derived from forest- or peatlands, and contributions to biodiversity conservation, if grown on a landscape mosaic.

In response to mounting criticisms, in 2004, the Roundtable on Sustainable Palm Oil (RSPO) was initiated, with the aim of enhancing value chain collaboration in the context of certification. The case of palm oil demonstrates that intensification driven by vicious value chains is likely to result in a non-sustainable landscape transition. Hence, scholars have increasingly called for the integration of environmental and social standards into value chains to ensure greater sustainability at the landscape level (Bolwig et al., 2010, Ros-Tone et al., 2018).

Kissinger et al. (2015) point to the increased interest of downstream value chain actors in sustainable sourcing to ensure quality management of raw material and stable supply and to facilitate marketing in sustainability-sensitive consumer markets. Some of the most prominent examples are certified coffee and banana value chains targeting Western markets (Muradian et al., 2011; Liu 2008). Indeed, demonstrating compliance with good social and environmental standards is gaining importance as a value chain upgrading strategy to access lucrative consumer markets with increased sensitivity to sustainable production (Nutz \& Sievers, 2015). Beyond producers, consumers have the power-precisely through their awareness and consumption choices-to exert influence on the sourcing landscapes. Related to this, an increased demand for organic, zero-deforestation, climate-friendly and fair-trade products may support both producers and processors as they adopt landscape-based standards.

Voluntary self-commitments in sourcing have emerged as a common response of international corporations in coping with mounting public pressure on them, albeit with little success in achieving more sustainability at landscape level. In complex, long and non-integrated value chains with multiple suppliers, as shown by Lyons-White and Knight (2018) for the case of palm oil, no-deforestation commitments failed due to colliding perceptions among local and international value chain actors regarding 'forests' and 'deforestation' definitions, weak national laws and complex, often nontransparent chain structures. Supply chain stickiness, as demonstrated by Leijten et al. 2022 for the case of soy production and trade in Brazil, leading to regional dependencies in sourcing, is another hampering factor. Hence, if self-commitments to be successful, they must be framed and institutionalized based on clearly defined 
standards, goals and regulations, for which we consider certification schemes, enforced and monitored by independent third-party auditing agencies, may serve as an appropriate method.

Introducing standards in sustainable sourcing requires a change in perspective on value chains-one that recognises how vertical value chain relations increasingly intersect with horizontal relations at the landscape level. This becomes clearer when looking at the interface between the value chain and the landscape approach. Beyond the product scope, it is relevant to consider how value chains affect the land-use decisions of smallholders and their production models, biodiversity and climate protection, food security and local political economies in which landscapes are embedded. Using a certified cacao production scheme in Ghana as an example, Deans et al. (2018) elucidate how value chain upgrading through advanced collaboration between smallholders and buyers has led to multiple positive outcomes at the landscape level. Social and ecological certification standards were introduced jointly with smallholder cocoa growers as a value chain upgrading strategy. Increased yields, a price premium and enhanced competitiveness benefited both smallholders and buyers, whilst good environmental practices (non-toxic fertiliser, shade trees, etc.) provided co-benefits to the landscape and allowed for long-term partnership building amongst chain actors. From amongst certification schemes geared towards tropical productions, such as those for soy, coffee and palm oil, forest certification has evidently been useful in supporting farmers' livelihood and improving the environmental conditions of production units and surrounding landscapes (Kissinger et al., 2015).

\subsection{State restrictions and forest certification for value chain upgrading and sustainable FLR promotion}

To a large degree, the value chain impacts of forest-based products on (forest) landscapes are determined by chain governance structures. Beyond endogenous factors shaping chain governance, there exists a wide range of external factors at different scales, including international agreements as well as national legislation and policies defining social, ecological and other standards in timber sourcing and processing. One prominent example from the forest sector is the Forest Law Enforcement, Governance and Trade (FLEGT) Action Plan initiated by the EU to tackle illegal logging and deforestation in timber-producing countries in Asia, Africa and South America. As one of the largest timber consumers worldwide, the EU seeks to avoid negative impacts on the environment and communities living in sourcing landscapes with high rates of illegal timber extractions. Thus, as a regulatory policy instrument, the FLEGT has prohibited imports of illegally harvested timber into the EU since 2013. Be it timber or processed wood products, tropical countries with voluntary partnership agreements with the EU engage in a chain of custody procedures that facilitate the export of wood products to the EU.

Aside from state-run auditing systems, third-party certification through private organisations has also played an increasingly important role in forestry and forest product value chain governance. Certified timber or non-timber forest products usually enjoy advanced access to lucrative export markets in industrialised countries and are often able to yield price premiums. The most prominent certification organisation in forestry is the Forest Stewardship Council (FSC), a non-profit organisation founded in 1993. As an international organisation, the FSC offers certification services in sustainable forest management and chain of custody certification for any chain actors using or selling FSC-certified material and products. Forest management certification targets a wider range of forest owners, ranging from smallholders to large corporations. Amongst others, the FSC standard includes sustainable silviculture practices, 
ecosystem and environmental value maintenance, good social standards for forest workers and ensuring the economic and social well-being of local communities (FSC 2015). Similar certification services are offered by the Programme for the Endorsement of Forest Certification (PEFC, 2018). Based on 16 case studies in developing and transitioning countries, Cashore et al. (2006) confirm that forest certification has a range of positive effects on power relations, workers and communities, business and the environment. This reinforces the idea that value chains of certified timbers are more advanced, thus garnering higher benefits for producers and performing better in environmental terms. Hence, regulated in the sense of certified commodity chains constitute beneficial instruments that can be used in integrated landscape approaches.

The abovementioned certification organisations require forest owners to maintain, conserve and/or restore ecosystem services and environmental values of the production units; to avoid, repair or mitigate negative environmental impacts; and to protect rare and threatened species, along with their habitats, through conservation zones, protection areas and connectivity. More importantly, forest owners also have the responsibility of managing the landscape around the production units to maintain and/or restore a varying mosaic of species, plant sizes, plant ages, spatial scales and regeneration cycles appropriate to the landscape values within a region. These requirements correspond well with a core FLR principle, which is to maintain and enhance natural ecosystems within landscapes (Bonn Challenge, 2019). We thus assume that harnessing certification as a value chain upgrading strategy may be appropriate in production-driven forest landscape restoration, not only to meet ecological standards, but also social standards, if smallholders and their livelihoods are duly considered. To testify this hypothesis, and understand under which conditions it could work, the ensuing section consider the case of acacia-based forest landscape restoration in Vietnam.

\section{PRODUCTION-DRIVEN AND INCLUSIVE FLR IN VIETNAM: THE CASE OF ACACIA}

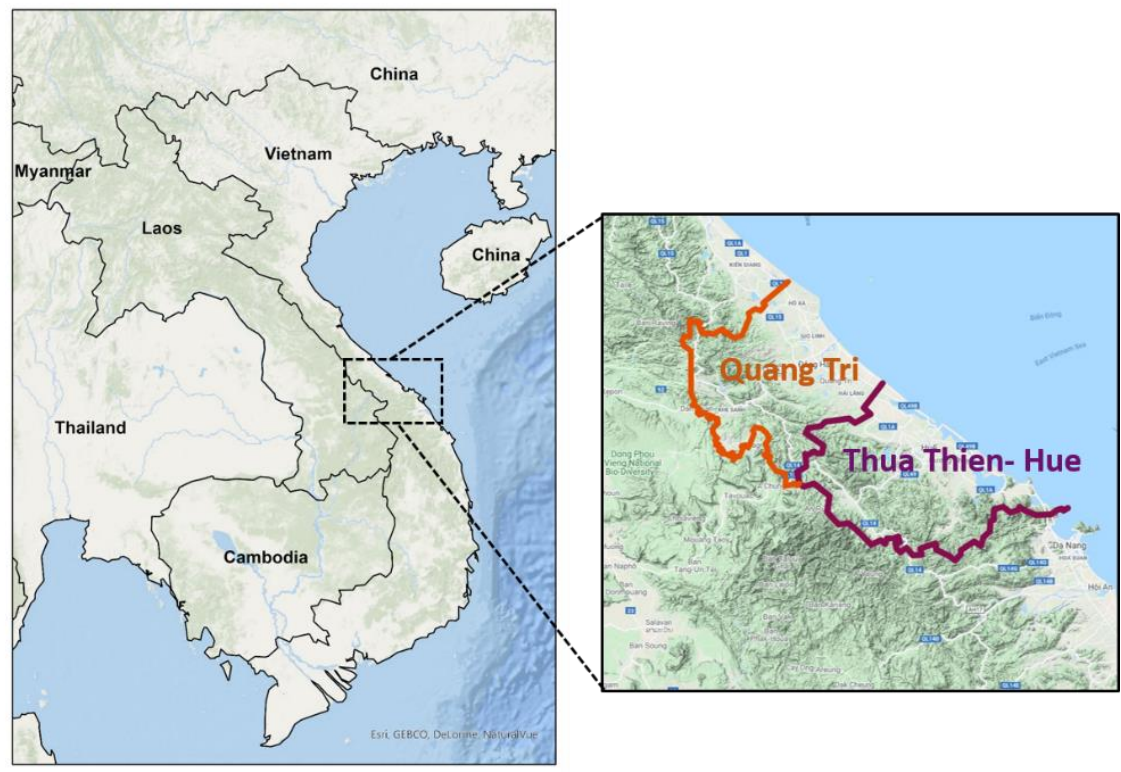

Figure 1. Map of Vietnam, Quang Tri und Thue Thien Hue, modified from google map 
In this section, we examine the case of Vietnam and shed light on the pathway of production-driven FLR as a process of value chain establishment and upgrading. To this end, we use secondary data stemming from recent studies dealing with the prominent role acacia has played in the reforestation of degraded land and rural development in the Vietnamese uplands. Apart from a macro-level analysis, we also refer to two case studies for micro-level analysis. More precisely, we look at two smallholder-based group forest certification schemes as examples of acacia value chain upgrading in the provinces of Quang Tri and Thua Thien-Hue.

\subsection{FLR in Vietnam}

After decades of runaway deforestation due to armed conflicts, industrial-scale logging and rapid agriculture expansion, Vietnam's forest cover has increased profoundly from just $27 \%$ in 1990 to almost 42\% in 2019, covering an area of 14.5 million hectares (ha) (MARD, 2019). Thus, Vietnam can be considered an international success story in forest restoration. However, only $8 \%$ of the forests can be classified as rich and medium-rich natural forests (MARD, 2015), whilst about $33 \%$ are degraded (Pham et al., 2012). The large expansion of forest areas resulted from a national policy shift away from forest exploitation towards rehabilitation and corresponding reforestation programmes initiated by the Government of Vietnam (GoV), with support from the international donor community. Short-rotation, fast growing species, such as acacia, eucalyptus and pine, for commercial use play a paramount role in this process. The expansion of tree plantations is also the main approach pursued by the GoV to attain a target of $47 \%$ forest cover by 2020 (MARD, 2015).

Whether forest restoration in Vietnam should be considered a kind of FLR is somewhat controversial and is a matter of perspective. The two nationwide forest rehabilitation and reforestation programmes started in 1992 with the 'Green the Barren Hills' programme (or Programme 327), which aimed to re-green open land and barren hills, protect existing forests, assist natural regeneration and reforestation and promote social welfare (Jong et al., 2006). This programme was followed by the Five Million Hectare Reforestation Project (5MHRP) from 1998-2010. The target of the 5MHRP was to reforest about 2 million ha of protection forest and 3 million ha of production forest.

The aforementioned reforestation programmes would not have been possible without the preceding institutional changes in the wake of Vietnam's transition from a state-run subsidy economy to a market economy. The de-collectivisation of agriculture in the late 1980s was followed by land reforms in the 1990s. In particular, the promulgation of the first Forest Protection and Development Law (1991) paved the way for land allocation and forest devolution to households. This involved tens of thousands of smallholders throughout Vietnam who were actively involved in the FLR.

For the first time, a modern forest land classification and management system was introduced based on three forest land types: (1) special use forest, (2) protection forest and (3) production forest. Whilst the two former categories aim at conservation in national parks and watershed areas, production forests opened up new opportunities for commercial forestry as a vehicle for production-driven reforestation (Jong et al. 2006). Incentives were provided via state-fostered access to seedling, extension services and access to credits. Hence, forest restoration served the dual purpose of (1) landscape restoration and (2) rural development. The latter not only included poverty alleviation and livelihood diversification but also eradication of shifting cultivation and modernisation of the upland farming system by including trees (Sandwall et al. 2010). In the absence of large-scale, concession-based private investments, the bulk of tree plantations in Vietnam are now owned by households holding 1-5 hectares each (Sikor 2012). Thus, smallholders have greatly contributed to the emerging agriculture-forest mosaic landscapes comprising a mix of paddy land, upland fields, tree plantations and 
protected watershed forests (Figure 2). The GoV has also acknowledged that forest degradation and rehabilitation must be addressed through an integrated approach in which local stakeholders and their livelihoods must be linked with ecological objectives in the landscapes.

During the same period, Vietnam has also established a flourishing wooden furniture industry, with some 3,000 small and medium-sized enterprises earning about USD10.3 billion in exports in 2019, marking an increase of $22 \%$ compared to 2018 (VIFOREST et al., 2020). However, as the bulk of domestically grown timber is of low value and is non-certified, Vietnam's furniture industry depends as much as $80 \%$ on foreign wood supply. In response, the GoV has pushed for an increase in the share of high-quality and certified domestic wood supply from plantations (Hoang et al., 2015b, Pistorius et al., 2016).

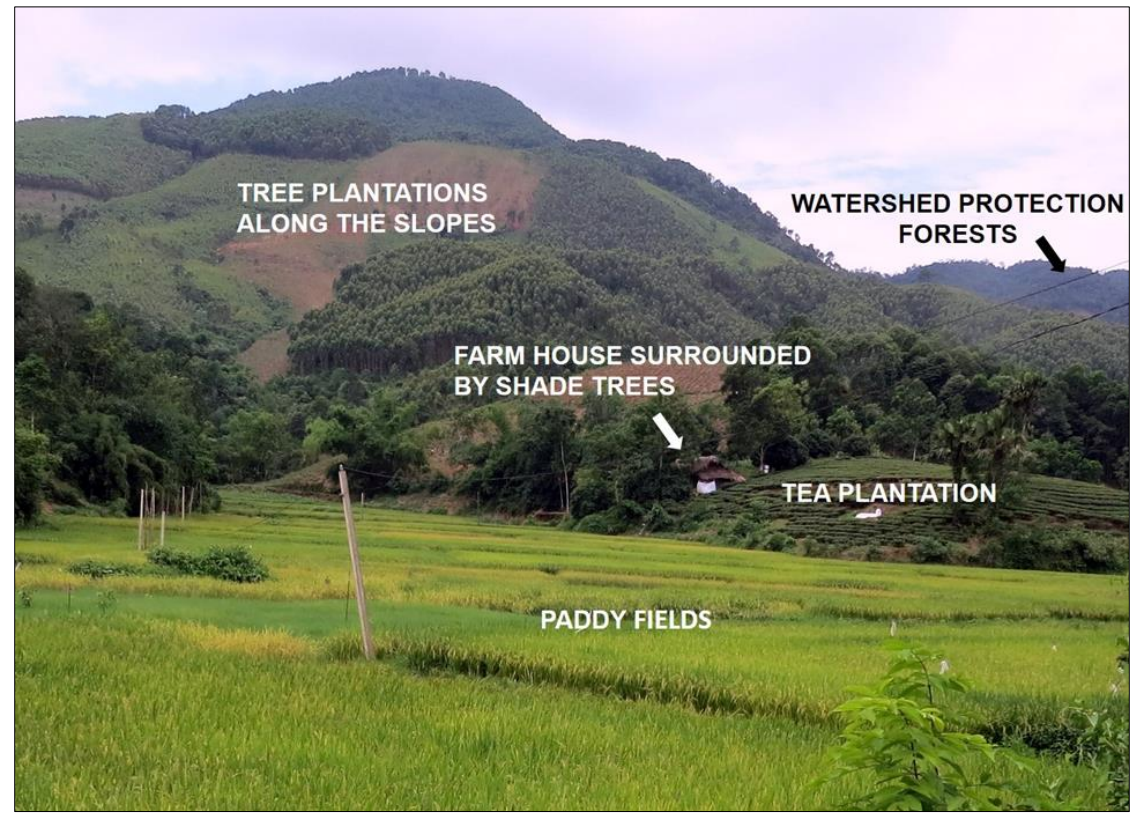

Figure 2. Typical agriculture-forest mosaic landscape in Yen Bai Province, Vietnam

\subsection{The acacia boom in Vietnam}

Acacias were first introduced to the southern and northern parts of Vietnam in the 1960 s and 1980s, respectively. By 2013, more than half of the plantation area was covered with acacia species: 600,000 ha with acacia mangium, 400,000 ha with clonal acacia hybrid (A. mangium $\times$ A. auriculiformis), 90,000 ha with A. auriculiformis and 5,000 ha with A. crassicarpa (Kien et al., 2014, Nambiar et al., 2014). The prominent role of acacia in restoration is particularly related to its nitrogen-fixing capacity, which is essential for the rehabilitation of heavily degraded soils and barren lands. Further, acacia is highly favoured due its fast growth rate and short rotation cycles, making it an ideal input for the low-return business model based on large and reliable supply chains that have emerged over the past 20 years. Nearly half of all acacia plantations are managed by smallholders, whilst the rest are scattered across state forest enterprises and private companies (Pistorius et al., 2016). Without formal contracts, smallholders commonly sell their standing trees to local traders who then do the felling and preprocessing before selling them to processors in the domestic pulp, woodchip or furniture industries. 
Acacia has played a significant role in Vietnam's economic development with two predominant products: wood chips and sawlogs (Pistorius et al., 2016). Wood chip production has well-established and low-value acacia wood value chains. About $70 \%$ of Vietnamese acacia wood is chopped for chips and exported to regional markets, such as China or Japan (Maraseni et al., 2017). Meanwhile, sawlog production, with and without third-party sustainable forest management certification, has serviced both domestic or international markets. The demand for wood by Vietnam's booming furniture industry is high and constantly increasing (To et al., 2017).

Despite the socio-economic significant role acacia plays in fostering rural development in upland areas, its vast spatial expansion in monocultures and resulting landscape dominance have also raised concerns in many respects. On the one hand, low-value acacia value chains promoted the reforestation of large areas of barren land and local wood industry development. On the other hand, the rapid expansion of acacia plantations has led to low biodiversity, high risks of diseases and forest fire as well as low resilience against climate change (Rizzeti et al., 2016).

\subsection{Efforts for sustainable forest certification in Vietnam as a value chain upgrading strategy}

Following an empirical assessment of Vietnamese value chains, Tham et al. (2021) reported that although acacia wood-chip value chains are financially profitable (about $26 \mathrm{USD} / \mathrm{m}^{3}$ ), they score poorly in terms of economic development due to their low value-added. In comparison, acacia furniture value chains (about $557 \mathrm{USD} / \mathrm{m}^{3}$ ) and FSC-certified furniture value chains (about $663 \mathrm{USD} / \mathrm{m}^{3}$ ) economically perform much better. Thus, they recommend that the latter value chains should receive greater attention in terms of government policies. Indeed, forest certification has been strongly promoted by the GoV since the early 2000s.

In 2007, the Ministry of Agriculture and Rural Development (MARD) announced the target of expanding forest areas under certification to 2 million ha by 2020 . However, this target was then scaled back to 500,000 ha by another ministerial decision in 2015 due to various challenges of third-party certification requirements, low-level forest management systems and restricted financial resources (MARD 2015; Ha 2018). To date, about 240,000 ha of forest received certification from the FSC (FSC, 2019; MARD, 2019), the most globally prominent international forest certification scheme. Recently, the GoV also started collaborating with the Programme for the Endorsement of Forest Certification (PEFC) schemes, another globally renowned certification scheme (MARD, 2019). Meanwhile, the Vietnam Forest Certification System (VFCS) was established in 2018 through the Prime Minister's decision, No. 1288/QD-TTg (GoV, 2018), based on the PEFC's principles and systems of forest certification (MARD, 2018).

Apart from the need to improve environmental values and sustainable forest management, the growth of forest certification in Vietnam is driven by several key factors. The first factor is the need to respond to the rising sustainability and legality requirements of public procurement policies (e.g., the European Timber Regulations or the Lacey Act of the United States) of many countries, which are considered major import markets for Vietnamese timber products (To et al., 2017). Meeting these requirements is particularly critical for Vietnam to maintain the current high growth rate of its exporting timber industry. Given that the demand for certified, high-quality timber is rising (To et al., 2017), in response, the GoV is striving to transform the current low-value wood chip plantations into high-value timber plantations through prolonged rotation and certification (Maraseni et al., 2017).

Second, and equally important, global retailers are also steadily putting more pressure upon wood supply chains by requiring certified products. For instance, IKEA 
Corporation, one of the main global buyers, has requested $100 \%$ FSC-certified timber products from Vietnam since September 2017 (To et al., 2017). Other giant global retailers, such as Walmart (Walmart, 2020) and John Lewis (John Lewis, 2020), require their sourcing materials to be certified, and FSC and PEFC are both equally accepted in their sourcing procurement policies.

Finally, it is also expected that forest certification can serve as an important instrument to improve farmers' livelihood, strengthen their skills and capacities in sustainable forest management and ensure better forestry outcomes (Auer, 2012). This objective is pivotal, because about 4.1 million ha of plantation forest are managed by smallholder farmers, many of whom adhere to outmoded forest management practices with low economic values and negative impacts on the environment (MARD, 2019; Pistorius et al., 2016). Given that the Vietnam forest certification scheme under the PEFC is still in an early stage of development, our analysis will focus on FSC, which has been implemented over the last 20 years.

\subsection{Impacts of group certification on FLR: The cases of Quang Tri and Thua-Thien Hue}

The previous section adopted a macro perspective on Vietnam's production-driven and smallholder-based forest landscape restoration pathway. Next, we will provide a micro-perspective on value chain upgrading options for additional landscape-level ecological and socio-economic benefits through certification. To this end, we will look at two case studies of FSC forest group certification schemes in the two provinces, Quang Tri and Thua Thien-Hue, which are neighbouring provinces in Central Vietnam (see figure 1).

\subsubsection{Case study 1: FSC group certification in Quang Tri Province}

To understand the potential impacts of certification-based value-chain upgrading on FLR, we draw on the example of an FSC group certification scheme in Quang Tri Province, Vietnam (hereinafter referred to as the Quang Tri certification group). This specific group represents the first smallholder-based certification group in Vietnam. It was initiated in 2007 by the World Wide Fund for Nature (WWF) and the Swiss Agency for Development and Cooperation, with political support from provincial authorities (Auer, 2012). The group was first certified in 2010, overseeing a plantation area of 270 ha belonging to 315 households. As of 2019, the certified area has increased to 1,920 ha, belonging to 520 smallholders (FSC, 2019). All certified sawlogs produced by the group are bought directly by companies belonging to the Global Forest and Trade Network under WWF facilitation. The products are sold at higher prices compared to non-certified sawlogs. Furthermore, due to the high demand for certified timber, growers are in a position to choose buyers who offer the best prices and terms of trade (Auer, 2012; Hoang et al., 2015a). In addition, by selling directly without a middleman, there are lower transaction costs for the producers. Equally important, the certified timber is sold per cubic metre rather than selling the standing trees on the stock per hectare, which is subject to the estimation of a middlemen. This new transparent practice benefits growers, who are usually unable to accurately estimate the growing stock of their plantation (Hoang et al., 2015a). Actually, all timber produced by the group until 2020 is guaranteed to be bought at favourable conditions and fair prices by a furniture production company that is engaged closely with the group ( $\mathrm{Ha}, 2018)$. As a result, the reported price of FSC-certified acacia timber paid by the local company to the smallholders increased by 10\%-17\% compared to (local) market prices for noncertified acacia sawlogs (Auer, 2012; Hoang et al., 2015a \& b). It must be noted that higher prices are not a requirement in FSC certification, but should-and often doemerge as a positive effect. 
In the case of the Quang Tri certification group, higher prices are accepted by the buyer due to its interest in sustaining long-term sourcing of FSC-certified raw materials, which are currently rare in Vietnam (personal communication with WWF project managers and the buyer company, February 2020). Moreover, the price premium emerges under a subsidy system, as the actual transaction costs of certified timber are beyond the financial capacity of smallholders. In fact, both the financial and technical expenses of achieving and maintaining the certificate are still mainly sponsored by external stakeholders, including international donors or private companies, together with a very small contribution from the group participants ( $\mathrm{Ha}, 2018)$. At the same time, certification has not only strengthened value chain governance and upgrading in economic terms, but has also contributed to the development of smallholders' skills and awareness in sustainable forest management. This includes improved silviculture skills, such as planting of seedlings, tracking of annual forest growth, thinning and felling. In recent years, farmers have been trained in plantation inventory methods and harvesting planning. A pre-assessment carried out by a third-party auditor found that farmers previously had clear-cut plots with bulldozed and ploughed soils prior to planting acacia seedlings (Sloth \& Le, 2009). Forest productivity measures are now reported in project notebooks. In addition, more sustainable practices have replaced the conventional ones with negative environmental impacts, especially those related to excessive soil preparation, fires, pesticides and fertiliser usage. Participating growers have also agreed to prolong the rotation of their plantation up to eight years, which is much longer than the common practice of four- to five-year rotations (WWF, 2016 unpublished data).

Hence, in this example, certification was instrumental in improving the environmental conditions of not only production units but also adjacent areas. As stipulated, producers under the FSC scheme have to leave buffer strips along the watercourses, including both riparian areas and ponds, for environmental benefits. The buffer areas are planted with a mix of acacia and high-value native hardwood species, such as Hopea odorata (Auer, 2012). Growers are also required to apply low-impact harvesting techniques to reduce the physical impacts of harvesting on soil and ground conditions. Moreover, high conservation value assessments have also been conducted, with the aims of preserving natural understorey trees, thus reducing environmental impacts of future rotations and minimising biodiversity loss in monoculture plantation. This also demonstrates that certification does not only consider environmental conditions within the production units but also those of adjacent land patches within the larger landscape.

As a result of certification, value chain governance has been upgraded through enhanced cooperation amongst smallholders in a horizontal direction and an emerging partnership between growers and the private sector in a vertical direction. Over the years, the group structure has developed from a loosely structured group of farmers to a basic legal entity and, finally, to a formally registered entity. The Association of Quang Tri Smallholder Forest Certification Groups is now legally recognised by the Quang Tri Provincial People's Committee. Through this organisation, direct cooperation between producers and buyers has been significantly strengthened. Amongst other benefits, the company has agreed to provide financial and technical support to enable the Quang Tri FSC group to maintain its certificate and to purchase all timber produced by the group until 2020. A 15\%-17\% price premium compared to market prices is also guaranteed for FSC-certified timber produced by the group, with some minimum requirements in terms of diameter and plantation age ( $\mathrm{Ha}, 2018)$. 


\subsubsection{Case study 1: FSC group certification in Quang Tri Province}

The TTH-FOSDA is another smallholder-based FSC certification scheme. It was established in 2015 through a collaboration between the WWF and the Thua Thien-Hue Forest Protection Department (Thua Thien-Hue FPD) (Ha, 2018; FSC, 2020). The TTHFOSDA can be considered a 'sister model' of the Quang Tri group discussed above, yet with a range of improvements and advantages in terms of group structure, partnership relations and cost and benefit sharing mechanism. These improvements have allowed the TTH-FOSDA to expand and overcome some limitations faced by the Quang Tri Group. In particular, the TTH-FOSDA has expanded at a relatively fast pace since its foundation. For the first time, it obtained the FSC forest management certificate in 2016 with an area of almost 1,000 ha. By 2020, 4,720 ha, belonging to 948 forest smallholders, had been certified under the TTH-FOSDA (FSC, 2020; WWF, 2019).

Regarding its organisational structure, the TTH-FOSDA is somewhat similar to the Quang Tri Group, comprising the board committee at the provincial level and subassociations at the local level $(\mathrm{Ha}, 2018)$. However, a closer look reveals a number of notable differences. For one, the majority of sub-associations of the Quang Tri Group are self-established groups of small-scale forest owners who come from the same village or commune and share common interests in applying forest certification. In comparison, 19 out of 35 sub-associations of the TTH-FOSDA are registered as cooperatives. The cooperatives are legally entitled businesses under the Law of Cooperatives and, therefore, enjoy many advantages in terms of management, leadership and political commitments ( $\mathrm{Ha}, 2018)$. The TTH-FOSDA also aimed to support and encourage the remaining sub-groups to undergo the process of upgrading into cooperatives, thereby raising the number of cooperatives to 30 by the end of 2020 (Personal communication with the FOSDA Vice Chairman, February 2020).

The Board Committee of the TTH-FOSDA includes representatives of the provincial government and the chairperson of 35 sub-associations and three private companies. Two of the latter are buyers who purchase all the sawlogs produced by the groups. The third is a private nursery that offers good-quality seedlings to the groups (Personal communication with the FOSDA Vice Chairman, February 2020).

There are four key stakeholders in the group who contribute to the development of the TTH-FOSDA group:

(i) Private sector: This consists of the two buyer companies that have a principal agreement with the TTH-FOSDA to buy all certified sawlogs produced by the group members at a favourable price compared to the market price of non-certified products. These companies also provide technical support to enable the TTH-FOSDA members to expand their certification areas. Additionally, they also offer financial support, such as responsibility for the surveillance audit costs, by the third-party certification body for the group.

(ii) Group members: These contribute membership fees as a way of sharing benefits gained from selling their certified products at higher prices.

(iii) External funders: These include the WWF-IKEA partnership (WWF, 2019) and the USAID Green Annamites Project (USAID 2019), both of which provide a reasonable amount of technical and financial support to the TTH-FOSDA.

(iv) The provincial government: Though this, the group has been given access to state-run promotion programmes on forest certification. The national decision 38/2016/QĐ-TTg requires the province to subsidise smallholders with VND 300,000 per certified ha (GoV 2016). Therefore, the group has managed to secure a combined VND 600 million (equivalent to USD 25,700) subsidy for the years 2018 and 2019 to pay for certification services once the external funding from donors runs out (Personal communication with the FOSDA Vice Chairman and WWF Project Manager, February 
2020).

The second case study demonstrates how a financial collaboration mechanism amongst the private sector, government, smallholders and external funders helped the TTH-FOSDA group overcome the technical and financial challenges of forest certification. Especially, the private sector has been dedicated and proactively engaged right from the beginning, thereby witnessing and reaping the benefits of stable and long-term sourcing of certified wood based on mutually beneficial partnerships with growers.

\section{CONCLUSION: TOWARDS A MULTI-STAGES MODEL IN PRODUCTION-DRIVEN FLR}

Today, there is an urgent need to mobilise FLR funding for the sake of climate protection and restoring/maintaining vital ecosystems around the world. As funding from state coffers can be quite limited, it has become increasingly relevant to think beyond conventional public-funded, conservation-driven FLR approaches. In this regard, increased private sector engagement points the way out of the funding impasse, although it requires a shift in perspective towards production-driven and marketoriented FLR. Value chains play a pivotal role in such a production-driven FLR approach, as they connect landscapes with local and global markets, along with the stakeholders involved within and beyond the landscapes where the sourcing of forest and agricultural products is taking place.

At the same time, we must not ignore the manifold social and ecological risks inherent in commercial restoration pathways that seek economic viability. Different configurations of value chain governance arrangements can have significant social and ecological impacts at the landscape level, both in negative and positive terms. In particular, unregulated and low-value commodity chains (vicious value chains) are more likely to generate negative than positive landscape outcomes, whilst regulated and high-value commodity chains (benign value chains) may promote positive landscape transitions, especially in terms of environmental integrity, local livelihood improvements and landscape governance.

The case of Vietnam demonstrates that FLR can be efficient and equitable when smallholders are included as agents in the mosaic landscape restoration of degraded forest land. As shown in Figure 3, the case of Vietnam vividly elucidates how the creation of an enabling institutional environment (land reforms, market reforms and forest devolution) in conjunction with smallholder inclusion as part of a productiondriven restoration pathway brought trees back into the landscape and contributed positively to rural development and livelihood diversification. Since the 1990s, many upland areas throughout Vietnam have been transformed into diverse agricultureforest mosaic landscapes consisting of paddy lands, upland fields, pastures, tree plantations and protected watershed forests. As we can learn from Vietnam in the early phase of forest landscape restoration, it was critical to support FLR through marketdriven approaches and promoting livelihood benefits through adequate policies that mobilized and enabled smallholders to grow trees.

Nevertheless, whilst acacia plantations brought trees back into landscape, provided additional income to rural communities through livelihood diversification and contributed to soil rehabilitation, the rapid spatial expansion of small-scale, monoculture tree plantations have become a limiting factor for achieving the goal of biodiversity conservation and proper ecosystem functioning at landscape level. Moreover, drawing on short rotation cycles (four to five years), acacia woodlots mainly supply materials for woodchip, paper and pulp production. Although paper and woodchip value chains are financially viable, from an economic perspective, they only 
create very low value-added. Accordingly, the incomes of stallholders engaged in acacia planting are stable but are at consistently low levels. At the same time, given the scarcity of domestically produced saw wood, Vietnam's export-oriented booming furniture industry has become heavily reliant on timber imports, including certified timber.

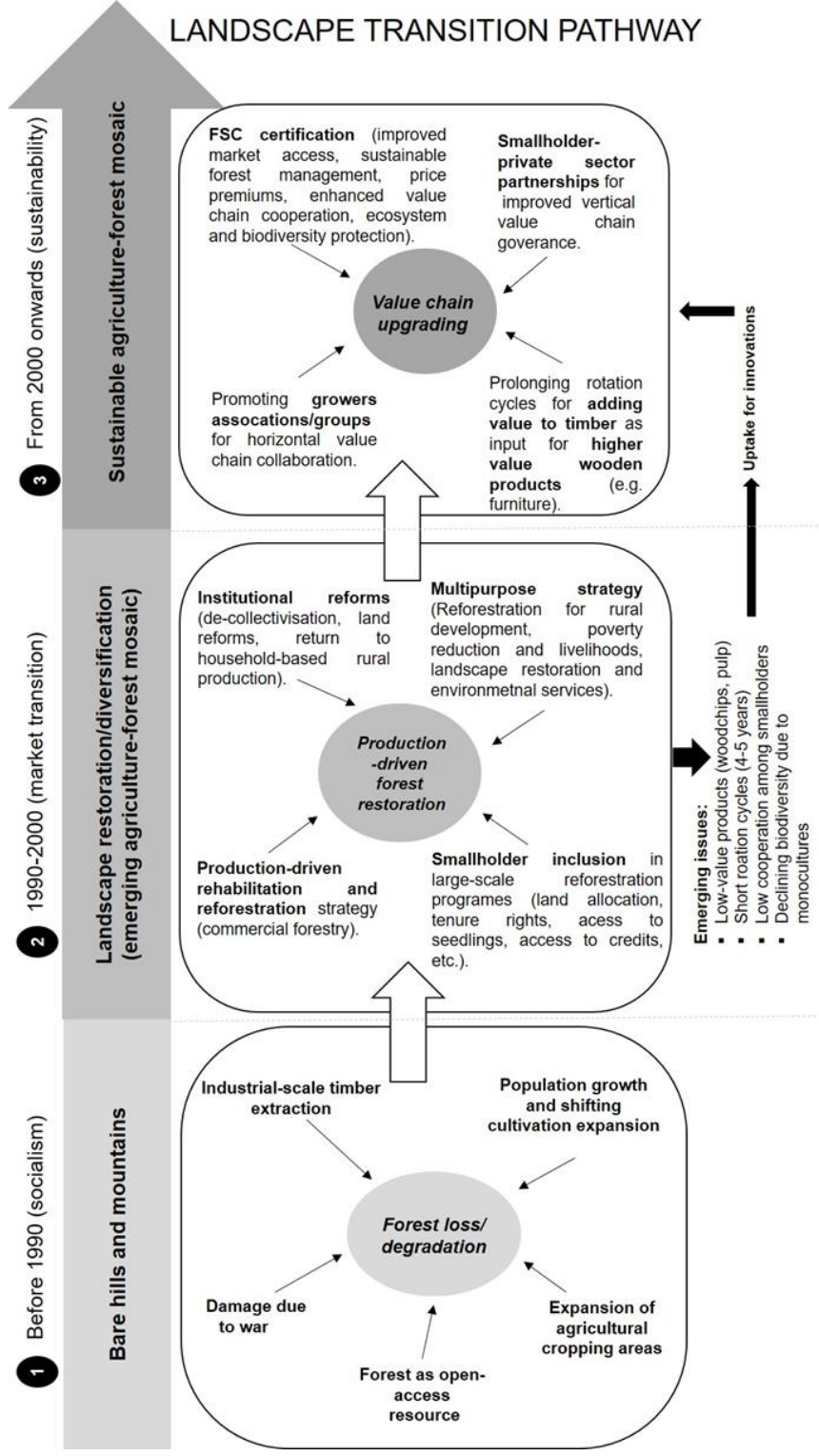

Figure 3. The FLR evolutionary pathway in Vietnam

The aforementioned shortcomings are now being increasingly tackled by government policies that aim to promote prolonged acacia rotation cycles for higherquality timber. Different from countries in the Global South that export unprocessed wood in the absence of domestic processing options, Vietnam's booming furniture industry may serve as a critical entry-point to promote value-chain upgrading to yield 
ecological and socio-economic benefits at landscape level. The strategy is to substitute wood imports, create more value-added within Vietnam's furniture industry and, ultimately, improve the incomes of acacia growers. Certification provides additional upgrading options, as it offers advanced access to export markets (e.g., European Union) with high (legal) entry barriers that require certification and chain of custody. As discussed previously, value chain upgrading through certification does not only benefit value chain stakeholders in socio-economic terms, but also generates positive effects on the sourcing landscapes and their ecological functionalities. A meta-analysis by Burivalova et al. 2017, comparing various case studies, concludes that forest certification can attain additional social and economic benefits, and to a lesser extent also ecological gains. Drawing on empirical evidence from community-based FSC in Tanzania, Kalonga et al. (2016) attribute forest certification a positive role in biodiversity conservation, and further highlight possible socio-economic benefits for smallholder communities in form of increased incomes (Kalonga et al., 2015).

Nevertheless, the number of skeptical, even critical perspective regarding the feasibility of smallholder certification schemes is large, hinting at the high financial and administrate costs and the challenge to comply with high standard procedures and requirements (Molnar, 2004). Indeed, as evident from our case studies in Vietnam, in the Global South, certification schemes are often externally initiated by third-party interventions through international donors, particularly non-government organisations (Wiersum et al., 2013; Gambetta et al., 2004). Beyond organisational matters, external support is needed to overcome high certification costs, which discourage smallholders from entering high-value, certified commodity chains (Perez-Aleman \& Sandilands, 2008). In connection to the high certification costs, the net price premium that farmers actually receive could be as low as 5\% (Flanagan et al., 2019), which is rather a disincentive. Our case studies are no exceptions in this regard. Initially, certification would not have been possible without external start-up financing. However, subsequent partnership development, particularly the active role played by the private sector, stabilised the scheme and helped ensure sustainability beyond the time when external support came to an end. As can be learnt from the TTH-FOSDA case, involving the buyers in the board committee proved to be beneficial for long-term partnership and trust building. Certification further stimulated the horizontal cooperation amongst smallholders and, with it, their voice and bargaining power. Strong ties and close cooperation amongst chain stakeholders are prerequisites in building communityprivate sector partnerships that enable certification for mutual benefits. Such partnerships may pave the way towards mature, profitable and financially selfsufficient value-chain arrangements.

Despite the justified criticisms, certification remains an appropriate tool for upgrading and sustainability configurations in value chains. This makes it an appropriate tool for production-driven FLR, as certification comes with multiple positive ecological and socio-economic effects at the landscape level. As indicated in Figure 3, Vietnam's production-driven FLR pathway can be depicted as a multi-stage model in which the first stage features the value chain establishment of low-value woodchip and paper production for which smallholder-based acacia plantations provided the sourcing base. Since 2000, drawing on value chain upgrading strategies Vietnam entered a new stage towards more benign value chains that strive for higher economic values (e.g., furniture), whilst simultaneously increasing sustainability at the landscape level. In this regard, certification, rolled out at larger scale, may serve as the next level in this stages model. Each stage adds new standards to FLR strategies, instead of maximising ecological, economic and social benefits right from the beginning of FLR processes when other factors such as financial viability are more critical than ecological aspects. 
It follows an adaptive strategy in which producers slowly, but gradually increase their sustainability performance. Apart from the FSC, the development of the national forest certification system for Vietnam (Vietnam Forest Certification Scheme), which is on its way to being endorsed by the PEFC, may trigger new impulses. Thus, by gradually improving the certification framework conditions for smallholders, certification could play a more important role in production-driven landscape restoration in Vietnam.

Author Contributions: Conceptualisation and study design, NTH, SB, GK; Data collection, NTH, SB; Data analysis, NTH, SB; Writing original draft, SB, NTH; Review and editing, GK, supervision, GK.

Competing interests: The authors declare that they have no conflict of interests.

Acknowledgments: We would like to thank the two anonymous reviewers for their critical and constructive feedback. This work was supported through the FLOURISH project [18_III_085_Southeast Asia_A_FLR Partnerships] under the International Climate Initiative (IKI), funded by the German Federal Ministry of the Environment, Nature Conservation and Nuclear Safety. The funding agency was not involved in this research.

\section{REFERENCES}

Agrawal, A., Cashore, B., Hardin, R., Shepherd, G., Benson, C. and Miller, D. (2013). Economic Contributions of Forests. Background paper prepared for the tenth session of the United Nations Forum on Forests held in Istanbul, 8-19 April 2013.

Arts, B., Buizer M., Horling L., Ingram V., van Oosten C. and Opdam, P. (2017). Landscape approaches: A state-of-the-art review. Annual Review of Environment and Resource 42, 439-463. https://doi.org/10.1146/annurev-environ-102016060932

Auer, M. R. (2012). Group forest certification for smallholders in Vietnam: An early test and future prospects. Human Ecology, 4O(1), 5-14. https://doi.org/10.1007/s10745-011-9451-6

Bolwig, S., Ponte S., du Toit, A., Riisgaard, L. and Halberg, N. (2010). Integrating poverty and environmental concerns into value-chain analysis: A conceptual framework. Development Policy Review, 28(2), 173-194. https://doi.org/10.1111/j.1467-7679.2010.00480.x

Bonn Challenge. (2019). Forest Landscape Restoration, 6 May 2019. Available at: http://www.bonnchallenge.org/content/forest-landscape-restoration

Brancalion, P. H. S. and Chazdon R. L. (2017). Beyond hectares: four principles to guide reforestation in the context of tropical forest and landscape restoration. Restoration Ecology, 25(4), 491-496. https://doi.org/10.1111/rec.12519

Burivalova, Z., Hua, F., Koh, L. P., Garcia, C. and Putz, F. (2017). A critical comparison of conventional, certified, and community management of tropical forests for timber in terms of environmental, economic, and social Variables. Conservation Letter, 10(1), 4-14. https://doi.org/10.1111/conl.12244

Cashore, B., Gale, F., Meidinger, E., \& Newsom, D. (2006). Forest certification in developing and transitioning countries: part of a sustainable future?. Environment: Science and Policy for Sustainable Development, 48(9), 6-25. https://doi.org/10.3200/ENVT.48.9.6-25

Cannell, M. G. R. (1999). Environmental impacts of forest monocultures, water use and acidification, wildlife conservation and carbon storage. New Forests, 17, 239262. https://doi.org/10.1023/A:1006551018221

Coles, C. and Mitchell, J. (2011). Working together - Horizontal coordination as an 
upgrading strategy. In J. Mitchell and C. Coles (Eds.), Markets and Rural Poverty: Upgrading in Value Chains (pp. 143-62). Earthscan.

Deans, H., Ros-Tonen, M. A. F. and Derkyi, M. (2018). Advanced value vhain vollaboration in Ghana's vocoa sector: An entry point for integrated landscape approaches? Environmental Management, 62(1), 143-156. https://doi.org/10.1007/s00267-017-0863-y

FAO (2015). The global forest resources assessment. FAO.

FAO and Global Mechanisms of the UNCCD. (2015). Sustainable financing for forest and landscape restoration - Opportunities, challenges and the way forward. FAO.

Flanagan, A. C., Midgley, S.J., Stevens, P.R. and McWhirter, L. (2019). Smallholder treefarmers and forest certification in Southeast Asia: Productivity, risks and policies. Australian $\quad$ Forestry, 18 , 18 -28. https://doi.org/10.1080/00049158.2018.1560569

Forest Stewardship Council (FSC) (2015) FSC International Standard, FSC Principles and Criteria for Forest Stewardship, FSC- STD-01-001-V5-2EN.

Forest Stewardship Council (FSC). (2019). 8 May 2019. Retrieved from http://fsc.force.com/servlet/servlet.FileDownload?file=00Pf300000wGHiXEA W

Forest Stewardship Council (FSC). (2020). Thua Thien Hue Forest Owners Sustainable Development Association (TTH-FOSDA) certificate information. Retrieved from https://info.fsc.org/details.php?id=a023300000d4nr8AAA\&type=certificate

Gambetta, F. C., Stoian, D., Campos, J. J., Cancino, J. M. and Pinelo, G. (2004). Forest certification in Guatemala. Yale School of Forestry and Envrionmental Studies. Yale School of Forestry \& Environmental Studies

Gereffi, G. (1999). International trade and industrial upgrading in the apparel commodity chain. Journal of International Economics, 48(1), 37-70. https://doi.org/10.1016/S0022-1996(98)00075-0

GoV. 2016-1: Decision no. 38/2016/QĐ-TTg, Policies on Protection, Development and Infrastructure Investment for Forestry Companies. Retrieved from https://thuvienphapluat.vn/van-ban/tai-nguyen-moitruong/Quyet-dinh-382016-QD-TTg-bao-ve-phat-trien-rung-dau-tu-ho-tro-ket-cau-ha-tang-congtynong-lam-nghiep-322052.aspx

GoV. 2018-1: PM Decision No. 1288/QĐ-TTg, Approval of the Sustainable Forest Management and Forest Certification program. Dated 1st October 2018. Retrieved from https://luatvietnam.vn/tai-nguyen/quyetdinh- 1288-qd-ttg2018-duyet-de-an-quan-ly-rung-ben-vung-va-chung-chi-rung-167561-d1.html

Gritten D., Greijmans M., Jihadah L. and Triraganon, R. (2018). Community forestry and forest landscape restoration: attracting sustainable investments for restoring degraded land in Southeast Asia. RECOFTC.

$\mathrm{Ha}, \mathrm{N}$. T. (2018). Local state actors and institutions and forest certification in Vietnam [Master thesis]. The Australian National University. Available at: http://ndeg.apps01.yorku.ca/wp-content/uploads/2018/02/Nga-Thi-HaMastersthesis.pdf

Helmsing, A. H. J. and Vellema, S. (2011). Governance, inclusion and embedding: Raising the issues. In Helmsing, A. H. J. and S. Vellema (eds.), Value Chains, Inclusion and Endogenous Development Contrasting Theories and Realities, (pp.1-16). Routledge.

Hoang, H.T., Hoshino, S. and Hashimoto, S. (2015a). Forest stewardship council certificate for a group of planters in Vietnam: SWOT analysis and implications. Journal of Forest Research, 20(1), 35-42. https://doi.org/10.1007/s10310-0140472-z 
Hoang, H.T., Hoshino, S. and Hashimoto, S. (2015b). Costs Comparison between FSC and Non-FSC Acacia Plantations in Quang Tri Province, Vietnam. International Journal of Environmental Science and Development, 6(12), 947-951. http://dx.doi.org/10.7763/IJESD.2015.V6.727

Ingram, V. (2014). Win-wins in forest product value chains? How governance impacts the sustainability of livelihoods based on non-timber forest products from Cameroon. African Studies Collection 56. African Studies Centre.

Issara, P., Adcharaporn, P., Popradit A., Ishida, A. and Somkid, U. (2019). Protected area co-management and land use conflicts adjacent to Phu Kao - Phu Phan Kham National Park, Thailand. Journal of Sustainable Forestry, 38(5), 486-507. https://doi.org/10.1080/10549811.2019.1573689

John Lewis. (2020). Sustainable timber and paper policy. Retrieved from https://www.johnlewispartnership.co.uk/content/dam/cws/images/tempfolde r/csr/johnlewis- timber-paper-policy-SRS015.pdf

Jong W. D, Do, D. S. and Trieu, V. H. (2006). Forest rehabilitation in Vietnam: histories, realities and future. CIFOR.

Kalonga, S. K., Kulindwa, K. A., \& Mshale, B. I. (2015). Equity in distribution of proceeds from forest products from certified community-based forest management in Kilwa District, Tanzania. Small-Scale Forestry, 14(1), 73-89. https://doi.org/10.1007/s11842-014-9274-6

Kalonga, S. K., Midtgaard F., Klanderud, K. (2016). Forest certification as a policy option in conserving biodiversity: An empirical study of forest management in Tanzania. Forest Ecology and Management 361, 1-12. https://doi.org/10.1016/j.foreco.2015.10.034

Kaplinsky, R. and Morris, M. (2001). A Handbook for Value Chain Research. Paper prepared for the IDRC. Retrieved from https://www.researchgate.net/profile/Mike-Morris-

11/publication/42791981_A_Handbook_for_Value_Chain_Research/links/00 b7d5173be8d93cc7000000/A-Handbook-for-Value-Chain-Research.pdf

Kapp, G. and Manning, D. (2014). Land management systems at the interface between forestry and agriculture. In Pretzsch, J., Darr, D and H. Uibrig (Eds.), Forests and rural development (pp. 85-110). Springer

Kien, N.D., Thinh, H. H., Kha L.D., Nghia, N. H., Hai, P. H. and Hung, T. V. (2014). Acacia as a national resource of Vietnam. Acacia 2014: Sustaining the future of Acacia plantation forestry. International conference. IUFRO Working Party 2.08.07: Genetics and silviculture of Acacia. Hue, Vietnam. 18-21.03.2014, Compendium of Abstracts.

Kilelu, C., L. Klerkx, A. Omore, I. Baltenweck, C. Leeuwis and Githinji, J. (2017). Value Chain Upgrading the inclusion of smallholders in markets: Reflections on contributions of multi-stakeholder processes in diary development in Tanzania. The European Journal of Development Research, 29(5), 1102-1121. https://doi.org/10.1057/s41287-016-0074-z

Kissinger, G., Moroge, M., Noponen, M. (2015). Private sector investment in landscape approaches: the role of productions standards and certification. In Minang $P$, Van Noordwijk M, Freeman OE, Mbow C, De Leeuw J, and D. Cataculan (Eds.), Climate-smart landscapes: multifunctionality in practice (pp. 277-292). World Agroforestry Centre (ICRAF).

Kröger, M. (2012). The expansion of industrial tree plantations and dispossession in Brazil. Development and Change, 43(4), 947-973. https://doi.org/10.1111/j.1467-7660.2012.01787.x

Lamb, D., Erskine, D.P. and Parrotta, A. J. (2005). Restoration of degraded tropical forest 
landscape.

Science,

$310(5754)$

1628-1632.

https://doi.org/10.1126/science.1111773

Leijten, F., dos Reis, T.N.P., Sim, S., Verburg, P.H. and Meyfroidt, P. (2022). The influence of company sourcing patterns on the adoption and effectiveness of zerodeforestation commitments in Brazil's soy supply chain. Environmental Science \& Policy, 128, 208-215. https://doi.org/10.1016/j.envsci.2021.10.032

Liu, P. (2008). Certification in the value chain for fresh fruits. The example of banana industry. FAO Commodity Studies 4. FAO.

Loffler, H. J. M., Afiff, S., Burgers, P. P. M., Govers, C., Heeres, H. J., Karyanto, O., ... \& Widyarani, R. (2014). Agriculture beyond food: experiences from Indonesia. NWO/WOTRO.

Lyons-White, J. and Knight, A.T. (2018). Palm oil supply chain complexity impedes implementation of corporate no-deforestation commitments. Global Environmental Change, 50, 303-313. https://doi.org/10.1016/j.gloenvcha.2018.04.012.

Maginnis, S. and Jackson, W. (2002). Restoring forest landscapes. IUCN.

Mansourian, S. (2016) Understanding the relationship between governance and forest landscape restoration. Conservation and Society, 14(3), 267-278. https://doi.org/10.4103/0972-4923.186830

Mansourian S. (2018). In the eye of the beholder: Reconciling interpretations of forest landscape restoration. Land Degradation and Development, 29, 2888-2898. https://doi.org/10.1002/ldr.3014

Maraseni, T. N., Hoang, L. S., Cockfield, G., Vu, H. D. and Tran, D. N. (2017). Comparing the financial returns from acacia plantation with different plantation densities and rotation ages in Vietnam. Forest Policy and Economics, 83, 80-87. https://doi.org/10.1016/j.forpol.2017.06.010

MARD. (2015). Forest Sector Development Report Year 2014. Forest Sector Support Program (FSSP) Annual Conference.

MARD. (2018). MARD decision no. 4691/QĐ-BNN-TCLN: Detailed implementation plan of the Sustainable Forest Management and Forest certification program. Dated 27th November 2018. Retrieved from http://thuvienphapluat.vn/van-ban/Tainguyen-Moi-truong/Quyet-dinh-4691-QD-BNNTCLN-2018-thuc-hien-De-anQuan-ly-rung-ben-vung-va-chung-chi-rung-401019.aspx

MARD. (2019-1). Vietnam forestry status and statistic, 2018, dated 19th March 2019. Retrieved from http://tongcuclamnghiep.gov.vn/content/uploads/files/2019.3.19\%20No\%20911.QĐ.BNN.TCL\%DBR2018.pdf

McDermott, G. A. (2007). The politics of institutional renovation and economic upgrading. Recombining the vines that bind in Argentina. Politics and Society, 35(1), 103-144. https://doi.org/10.1177/0032329206297185

Midgley, S. J., Stevens, P. R. and Arnold, R. J. (2017). Hidden assets: Asia's smallholder wood resources and their contribution to supply chains of commercial wood. $\begin{array}{lll}\text { Australian } \quad \text { Forestry, } & \text { 10-25. }\end{array}$ https://doi.org/10.1080/00049158.2017.1280750

Molnar, A. (2004). Forest certification and communities, International Forestry Review 6(2), 173-180. https://doi.org/10.1505/ifor.6.2.173.38393

Moyo, F., Funk, S. and J. Pretzsch (2017). Between policy intent and practice: Negotiating access to land and other resources in Tanzania's wildlife management areas. Tropical Conservation Science, 10, 1-17. https://doi.org/10.1177/1940082917744167

Muradian, R., Verschoor, G.M., Bolivar, E. and Ochoa, G. (2011). Building inclusive value chains in bio trade: a comparison of two cases from South America. In Helmsing 
A.H.J and S. Vellema (Eds.), Value chains, inclusion and endogenous development: Contrasting theories and realities (pp. 266-285). Routledge.

Nambiar, E. S., Harwood, C. E., \& Kien, N. D. (2015). Acacia plantations in Vietnam: research and knowledge application to secure a sustainable future. Southern Forests: $A$ Journal of Forest Science, $77(1), \quad 1-10$. https://doi.org/10.2989/20702620.2014.999301

Nambiar, E. S. (2019). Re-imagining forestry and wood business: Pathways to rural development, poverty alleviation and climate change mitigation in the tropics. Forest Ecology and Management, 448, 160-173. https://doi.org/10.1016/j.foreco.2019.06.014

Nutz, N. and Sievert, M. (2015). A rough guide to value chain development: A short guide for development practitioners, government and private sector initiatives. International Labour Office (ILO).

Overbeek, W., Kröger, M. and Gerber, J. F. (2012). An Overview over industrial tree plantations in the global South: Conflicts, trends and resistance struggles. EJOLT Report No. 3. International Institute of Social Studies of Erasmus University (ISS)

Owusu, R., Kimengsi, J. N., \& Moyo, F. (2021). Community-based Forest Landscape Restoration (FLR): Determinants and policy implications in Tanzania. Land Use Policy, 109, 105664. https://doi.org/10.1016/j.landusepol.2021.105664

Pacheco, P., Gnych, S., Dermawan, A, Komarudin, H. and Okarda, B. (2017). The palm oil global value chain: Implications for economic growth and social and environmental sustainability. Working Paper 220. CIFOR.

PEFC (2018). PEFC group forest management: PEFC Benchmark Standard. Retrieved from http://www.pefc.com.uy/data/documentacion/PEFC_ST_1002-2018__Group_Forest_Management_Certification_2018-11-14.pdf

Perez-Aleman, P. and Sandilands, M. (2008). Building value at the top and the bottom of the global supply chain: MNC-NGO partnerships. California Management Review, 51(1), 24-48. https://doi.org/10.2307/41166467

Pham, T.T, Moeliono, M., Nguyen, T.H., Nguyen H.T. and Vu, T. H. (2012). The context of REDD+ in Vietnam: Drivers, agents and institutions. CIFOR. https://doi.org/10.17528/cifor/003737

Pirker, J., A. Mosnier, F. Kraxner, P. Havlík and Obersteiner, M. (2016). What are the limits to oil palm expansion? Global Environmental Change 40, 73-81. https://doi.org/10.1016/j.gloenvcha.2016.06.007

Pistorius, T., Hoang, H. D. T., Tennigkeit, T., Merger, E., Wittmann, M., \& Conway, D. (2016). Business Models for the Restoration of short-rotation Acacia plantations in Vietnam. UNIQUE Forestry and Land Use GmbH. Retrieved from https://www.unique-landuse.de/images/publications/vereinheitlicht/AcaciaBusiness-Models-Vietnam.pdf

Pokorny, B. and De Jong, W. (2015). Smallholders and forest landscape transitions: locally devised development strategies of the tropical Americas. International Forestry Review, 17(1), 1-19. https://doi.org/10.1505/146554815814668981

Pye, O. and Bhattacharya, J. (Eds.) (2011). The Palm Oil Controversy in Southeast AsiaA Transnational Perspective. ISEAS.

Rasmussen, L.V., Watkins, C. and Agrawal, A. (2017). Forest contributions to livelihoods in changing agriculture-forest landscapes. Forest Policy and Economics, 84, 18. https://doi.org/10.1016/j.forpol.2017.04.010

Reinecke, S., \& Blum, M. (2018). Discourses across scales on forest landscape restoration. Sustainability, 10(3), 613. https://doi.org/10.1016/j.forpol.2017.04.010 
Ribot, J. (1998). Theorizing access: forest profits along Senegal's charcoal commodity chain. Development and Change, 29(2), 307-341. https://doi.org/10.1111/1467-7660.00080

Rizzeti, D., Swaans K., Holden J., Brunner J., Le, T. and Nguyen, T. (2018). Assessing opportunities in forest landscape restoration in Quang Tri, Viet Nam. IUCN.

Ros-Tone, M.A.F., Leynseele, Y.V., Laven A. and Sunderland, T. (2015). Landscapes of social inclusion: Inclusive value-chain collaboration: Through the lenses of food sovereignty and landscape governance. European Journal of Development Research, 27, 523-540. https://doi.org/10.1057/ejdr.2015.50

Ros-Tonen, M. A., Reed, J., \& Sunderland, T. (2018). From synergy to complexity: the trend toward integrated value chain and landscape governance. Environmental Management, 62(1), 1-14. https://doi.org/10.1007/s00267-018-1055-0

Sabogal, C., Besacier, C., \& McGuire, D. (2015). Forest and landscape restoration: concepts, approaches and challenges for implementation. Unasylva, 66(245), 310.

Sandewall, M., Ohlsson, B., Sandewall, R. K., \& Le Viet, S. (2010). The expansion of farmbased plantation forestry in Vietnam. Ambio, 39(8), 567-579. https://doi.org/10.1007/s13280-010-0089-1

Sawyer, J. (1993). Plantations in the tropics. Environmental concerns. IUCN.

Sayer, J., Sunderland, T., Ghazoul, J., Pfund, J. L., Sheil, D., Meijaard, E., ... \& Buck, L. E. (2013). Ten principles for a landscape approach to reconciling agriculture, conservation, and other competing land uses. Proceedings of the National Academy of Sciences (PNAS), 110(21), 8349-8356. https://doi.org/10.1073/pnas.1210595110

Sayer, J., Ghazoul, J., Nelson, P. and Boedhihartono, A. K. (2012). Oil palm expansion transform tropical landscape and livelihoods. Global Food Security, 1(2), 114119. https://doi.org/10.1016/j.gfs.2012.10.003

Sikor, T. (2012). Tree plantations, politics of possession and the absence of land grabs in Vietnam. Journal of Peasant Studies 39(3-4), 1077-1101. https://doi.org/10.1080/03066150.2012.674943

Sloth, C. and Le, C. U. (2009). Forest management pre-assessment report for: Linking trade demand for sustainable forest management project in Gio Linh and Vinh Linh Districts, Quang Tri Province. Unpublished document.

Snelder, D.J. and Lasco, R. D. (2008). Smallholder Tree Growing in South and Southeast Asia. In Snelder, D.J. and R. D. Laso (Eds.), Smallholder Tree Growing for Rural Development and Environmental Service: Lessons from Asia (pp. 3-33). Springer.

Darr, D., \& Pretzsch, J. (2021). Analysis of Acacia hybrid timber value chains: A case study of woodchip and furniture production in central Vietnam. Forest Policy and Economics, 125, 102401. https://doi.org/10.1016/j.forpol.2021.102401

Tran, T. M. A., Ko, D. W., Park, C. R. and Le, H. D. (2018). A bayesian network analysis of reforestation decisions by rural mountain communities in Vietnam. Forest Science and Technology 15(2), 51-57. https://doi.org/10.1080/21580103.2019.1581665

Trienekens, J.H. (2012). Value Chains in Developing Countries. A Framework for Analysis. In Van Dijk, M.P. and J. Trienekens (Eds.), Global Value Chains. Linking Local Producers from Developing Countries to International Markets (pp. 4368). Amsterdam University Press.

Trienekens, J.H. and van Dijk, M. P. (2012). Upgrading of Value Chains in Developing Countries. In Van Dijk, M.P. and J. Trienekens (Eds.), Global Value Chains. Linking Local Producers from Developing Countries to International Markets 
(237-250). Amsterdam University Press.

To, P.X., Nguyen, V.Q., Nguyen, T.Q. and Cao, T.C. (2017). Linkage between woodworking companies and forest plantation households: Upgrade value chain for wood industry. Forest Trend.

Van Dijk, M.P. and Trienekens, J. (2012) Global Value Chains. An Overview of the Issues and Concepts. In Van Dijk, M.P. and J. Trienekens (Eds.), Global Value Chains. Linking Local Producers from Developing Countries to International Markets (pp. 9-30). Amsterdam University Press.

VIFOREST, FPA Binh Dinh, HAWA, BIFA \& Forestry Trend. (2020). Report Vietnam import and export of timber and timber products: Status of 2019 and the trend in 2020. Retrieved from http://goviet.org.vn/upload/aceweb/content/Vietnam\% 202019\%20report.pdf

USAID. (2019). USAID Green Annamites Project. Retrieved from https://www.usaid.gov/sites/default/files/documents/1861/FS_USAID_Green _Annamites_Dec2019_Eng.pdf

Walmark. (2020). Certification and Validation. Walmark Sustainability. Retrieved from https://www.walmartsustainabilityhub.com/article/resources

Wiersum, K. F., Humphries, S., \& Van Bommel, S. (2013). Certification of community forestry enterprises: experiences with incorporating community forestry in a global system for forest governance. Small-scale Forestry, 12(1), 15-31. https://doi.org/10.1007/s11842-011-9190-y

WWF (World Wild Fund). (2016). Administration Handbook, association of households with forest certification in Thua Thien Hue (unpublished).

WWF (World Wild Fund). (2019). From humble beginnings in Central Vietnam, community leaders create anational model for sustainable forestry. WWF. 